University of Nebraska - Lincoln

DigitalCommons@University of Nebraska - Lincoln

Faculty Publications from the Harold W. Manter Laboratory of Parasitology

3-2-1979

\title{
Alveolar Hydatid Disease in Minnesota: First Human Case Acquired in the Contiguous United States
}

\author{
William G. Gamble \\ St. Louis Park Medical Center \\ Martin Segal \\ Methodist Hospital, Minneapolis \\ Peter M. Schantz \\ United States Center for Disease Control \\ Robert L. Rausch \\ University of Washington, rausch@u.washington.edu
}

Follow this and additional works at: https://digitalcommons.unl.edu/parasitologyfacpubs

Part of the Parasitology Commons

Gamble, William G.; Segal, Martin; Schantz, Peter M.; and Rausch, Robert L., "Alveolar Hydatid Disease in Minnesota: First Human Case Acquired in the Contiguous United States" (1979). Faculty Publications from the Harold W. Manter Laboratory of Parasitology. 535.

https://digitalcommons.unl.edu/parasitologyfacpubs/535

This Article is brought to you for free and open access by the Parasitology, Harold W. Manter Laboratory of at DigitalCommons@University of Nebraska - Lincoln. It has been accepted for inclusion in Faculty Publications from the Harold W. Manter Laboratory of Parasitology by an authorized administrator of DigitalCommons@University of Nebraska - Lincoln. 


\title{
Alveolar Hydatid Disease in Minnesota
}

\section{First Human Case Acquired in the Contiguous United States}

\author{
William G. Gamble, MD; Martin Segal, MD; Peter M. Schantz, VMD, PhD; Robert L. Rausch, DVM, PhD
}

\begin{abstract}
- A 56-year-old woman from southwestern Minnesota underwent an extended left hepatic lobectomy to remove a large multinodular mass with a necrotic central cavity. The clinical, serological, and pathological findings led to the diagnosis of alveolar hydatid disease, and specific identification of Echinococcus multilocularis was achieved by growing mature larvas in voles inoculated intraperitoneally with tissue from the hepatic lesions. The patient probably acquired her infection some years previously from pet cats or dogs that had become infected by ingesting infected rodents. In North America $E$ multilocularis is enzootic in the northern tundra zone of Alaska and Canada. Since 1964 the cestode has been recognized with increasing frequency in several north-central states, including Minnesota. The parasite may extend its range farther south, since suitable animal hosts occur throughout the United States.
\end{abstract}

(JAMA 241:904-907, 1979)

ALVEOLAR hydatid disease is an infection caused by the larval stage of the zoonotic parasite Echinococcus multilocularis Leuckart, 1863. The natural intermediate hosts of this cestode are small rodents. The natural definitive hosts for the tapeworm stage are foxes. Domestic dogs and cats are also susceptible definitive hosts and may become part of the life cycle when they prey on infected wild rodents. Although infections in carnivores are usually asymptomatic, their

From the Department of Surgery, St Louis Park Medical Center, St Louis (Dr Gamble); Department of Surgical and Clinical Pathology, Methodist Hospital, Minneapolis (Dr Segal); the Parasitic Diseases Division, Center for Disease Control, Atlanta (Dr Schantz); and Division of Animal Medicine, School of Medicine, University of Washington, Seattle (Dr Rausch).

Reprint requests to Parasitic Diseases Division, Bureau of Epidemiology, Center for Disease Control, Atlanta, GA 30333 (Dr Schantz). feces contain the eggs of the tapeworm, which are infective if accidentally ingested by susceptible intermediate hosts, including humans. In man the insidious, progressive growth of the hepatic larval lesion makes alveolar hydatid disease one of the most lethal of parasitic diseases. By the time the disease is clinically manifest, the lesion is often inoperable, and case-fatality ratios range from $50 \%$ to $70 \%$.

In North America $E$ multilocularis is enzootic in the northern tundra zone in cycles involving arctic foxes and their rodent prey. 'Since 1964 the cestode has been recognized with increasing frequency in animal hosts from several north-central states, including Minnesota; however, to our knowledge, infections in man had not been previously recognized in the contiguous United States.

\section{REPORT OF A CASE}

A 56-year-old woman was admitted to a local hospital in southwestern Minnesota on July 15, 1977, complaining of epigastric discomfort and malaise of several weeks' duration. Jaundice, dark urine, and acholic stools were noted three days before admission.

Examination showed epigastric fullness and the suggestion of a palpable mass. The alkaline phosphatase value was 556 IU, the bilirubin value was $13.4 \mathrm{mg} / \mathrm{dL}$, and the SGOT value was 48 units. The upper gastrointestinal (GI) series was normal.

Exploratory laparotomy was performed, and the surgeon reported metastatic carcinoma involving the left lobe of the liver. Further exploration of the abdomen did not show a primary site, and it was suspected that there was an occult primary carcinoma of the pancreas. The pathologist's report subsequently indicated cholestasia with periportal chronic inflammation and large zones of liver cell necrosis and hyalinization.

On July 25, 1977, the patient was transferred to a hospital in Minneapolis for further evaluation. Repeated serum chemistries suggested obstructive jaundice, and because of the uncertainty of the diagnosis, reexploration was performed. A multinodular, umbilicated, cystic, pale gray mass, $12 \mathrm{~cm}$ in diameter, was noted replacing the medial segment of the left lobe of the liver, with nodular extension into the lateral segment and slightly across the surgical plane between the right and left lobes.

Operative cholangiography demonstrated compressive obstruction of the common hepatic and main-branch intra. hepatic ducts by the large mass. A fullthickness biopsy specimen of the wall of 
the mass was examined by frozen section, and the pathologist reported probable echinococcal cyst disease. The cyst was decompressed through a large-bore external drainage catheter, with release of 450 $\mathrm{mL}$ of slightly turbid, serosanguineous fluid. Postoperatively the patient's condition improved dramatically, with rapid clearing of the jaundice, and she was discharged one week after surgery.

The patient was readmitted to the hospital on Oct 23,1977 , for definitive resection. On Oct 26 an extended left hepatic lobectomy was performed. The patient made an uneventful recovery and was discharged on the 16th postoperative day. She was treated with mebendazole at a dosage of $40 \mathrm{mg} / \mathrm{kg} /$ day, beginning three days preoperatively and continuing for four months. When last examined 12 months after hepatic resection, the patient appeared clinically well and had regained her normal weight and level of activity. Abdominal examination showed no evidence of hepatomegaly, the sinus tract had healed, and the liver function studies have remained normal, with the exception of mild elevation of the alkaline phosphatase level (60 IU). Liver scan showed no change in comparison with the postoperative examination.

\section{PATHOLOGICAL AND PARASITOLOGICAL FINDINGS}

The lesion involved the entire left lobe and a portion of the right lobe of the liver. The larval mass measured 12-cm maximum dimension, with a necrotic central cavity of 9 -cm diameter. The resected tissue weighed $335 \mathrm{~g}$. On cut surface the lesion consisted of pale, dense nodules and cystic areas surrounding the central cavity and infltrating liver tissue peripherally
(Fig 1). Microscopically the lesion contained numerous microvesicles lined by a laminated hyaline membrane surrounded by a granulomatous reaction and embedded in a dense connective-tissue matrix. Inside the laminated membranes, which stained intensely with periodic acidSchiff and Grocott methenamine silver stains, there were thin germinative layers that contained small nuclei (Fig 2). In the zones of cellular reaction, which occurred perifocally around the microvesicles, histiocytes preponderated, but lymphocytes, plasma cells, and eosinophils were numerous throughout. There were some areas of degenerative changes and necrosis. There was no indication of the formation of protoscolices or of calcareous corpuscles.

A portion of the freshly resected lesion was minced finely and inoculated intraperitoneally into six redbacked voles, Clethrionomys rutilus (Pallas), ten meadow voles, Microtus pennsylvanicus (Ord), and six jirds, Meriones unyuiculatus (Milne-Edwards). These laboratory-reared animals were killed at varying intervals between two and four months after inoculation. Viable cysts were observed in the peritoneum of two of the six red-backed voles. One lesion, examined four months after inoculation, had microscopic structure characteristic of larval $E$ multilocularis as described by Rausch and Wilson. ${ }^{2}$

Echinococcus antibodies, determined by three serological tests, were present in the patient's serum at low levels before resection of the lesion, increased notably immediately postoperatively, and then declined slowly (Table).

\section{EPIDEMIOLOGIC FINDINGS}

The patient had lived all of her life on farms within a $32-\mathrm{km}$ radius of her present residence in Lyon County, Minnesota. She had traveled out of the state on separate occasions to Hawaii (1975), Florida (1974), California $(1968,1973,1976)$, and Winnipeg, Manitoba (1963, 1970). The trips to Winnipeg involved overnight stays during which the patient recalled no contact with dogs, cats, or other animals.

The patient and her family had resided at the present farm for 22 years. The main products of the farm

\begin{tabular}{|cccc|}
\hline \multicolumn{4}{|c|}{ Echinococcus Antibodies ${ }^{*}$} \\
\hline Date & $\begin{array}{c}\text { Indirect } \\
\text { Hemagglutination }\end{array}$ & $\begin{array}{c}\text { Bentonite } \\
\text { Flocculation }\end{array}$ & $\begin{array}{c}\text { Immunoelectrophoresis, } \\
\text { Bands }\end{array}$ \\
\hline $8 / 2 / 77$ & $1: 256$ & $1: 10$ & 0 \\
\hline $11 / 13 / 77$ & $1: 2,048$ & $1: 160$ & $2 \dagger$ \\
\hline $3 / 27 / 78$ & $1: 128$ & $1: 20$ & $2 \ddagger$ \\
\hline
\end{tabular}

- Tests performed in parallel on all serum specimens at the Center for Disease Control, Atlanta. tIncluded Echinococcus-specific arc 5.

$\ddagger$ Weak bands, unidentified.

Fig 1.-Cut surface of resected liver specimen. Necrotic central cavity (lower portion) surrounded by pale, infiltrating granulomatous zone.

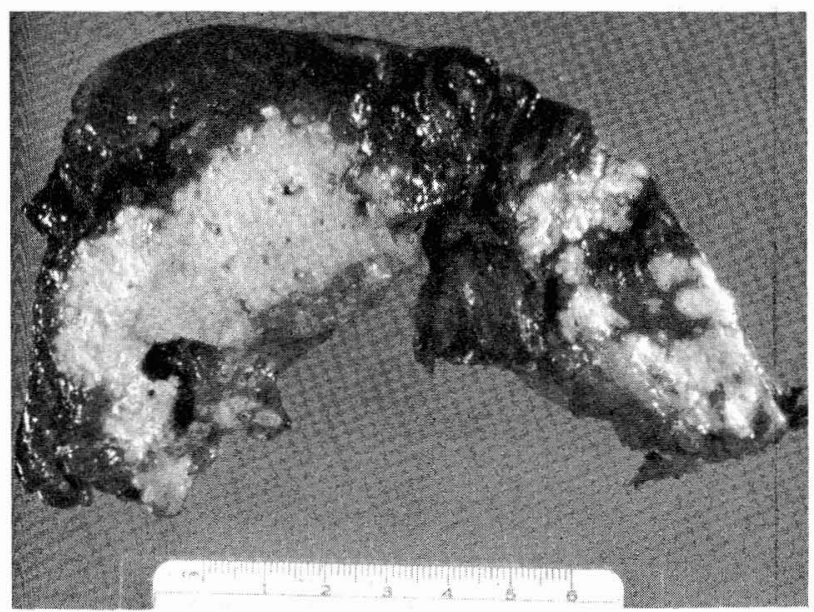

Fig 2.-Magnification of specimen. Thin germinative layers are seen inside laminated membranes (hematoxylin-eosin, $\times 300$ ).

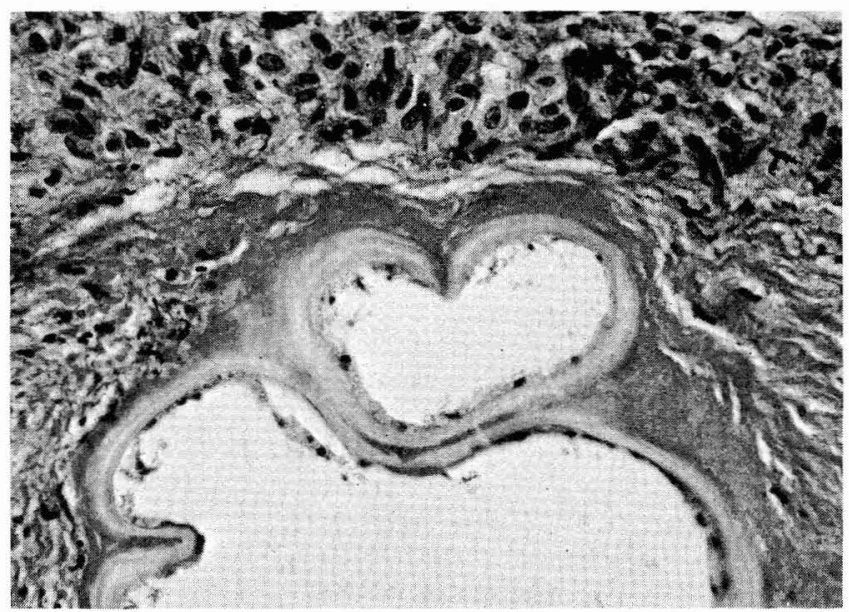


are soybeans and corn. A few cattle and sheep are kept but are never butchered on the premises. The family has always had at least one pet $\operatorname{dog}$ and five to ten cats. The cats and dogs do not enter the house, but the patient handled them occasionally while doing chores in the barn. The family has had the current pet dog for $1 \frac{1}{2}$ years, and stool specimens obtained from this dog and examined by the formalin-ether concentration technique on three consecutive days were negative for taeniid ova. Six house mice, Mus musculus (Linnaeus); and one deer mouse, Peromyscus maniculatus (Wagner), were trapped on the farm and were negative for infection by the larval cestode at necropsy.

Serum specimens collected from the patient's husband, son, daughterin-law, and granddaughter, who live on a neighboring farm, were nonreactive in serological tests for echinococcosis.

\section{COMMENT}

The clinical, serological, and pathological findings in this case led to the diagnosis of alveolar hydatid disease. The specific identification of $E$ multilocularis was achieved by recovery of mature larvas from laboratory-raised voles that had been inoculated intraperitoneally with suspensions of larval tissues from the hepatic lesion removed at surgery. The patient had not traveled to areas where human alveolar hydatid disease has been reported to occur; thus, to our knowledge, this is the first locally acquired case of $E$ multilocularis infection diagnosed within the contiguous 48 states. To our knowledge there are no previous reports from this geographic region, with the exception of three cases diagnosed in persons who had recently emigrated from other endemic areas where they had most likely acquired their infections. ${ }^{3.5}$

The primary localization of $E$ multilocularis larvas in human beings, as well as in natural intermediate hosts, is the liver. The larval mass proliferates indefinitely by exogenous budding, progressively invading the surrounding tissues, and resembles a malignant neoplasm in behavior and appearance. There may be metastases to the lungs or brain. In chronic infections the lesion consists of a central necrotic cavity filled by a white amorphous material and a thin peripheral layer of dense fibrous tissue that is extensively infiltrated by the proliferating vesicles. Protoscolices (mature larval units) are rarely observed in infections in man, and the histopathologic findings may be confusing; eosinophilic laminated hyaline material, necrotic liver tissue, and fibrous tissue are found in patternless disorder. It had been shown previously, however, that under conditions of an adverse parasite-host relationship, undifferentiated larval cells retain their generative potential, and when tissues containing such cells are transferred to a favorable host environment, histogenesis can occur normally. ${ }^{2}$ This characteristic was exploited in our case to permit confirmation of the causative agent as $E$ multilocularis.

The long-term prognosis for our patient is relatively favorable because most, if not all, of the larval cestode lesion was removed at surgery. To minimize chances for recurrence of larval growth, the patient was given oral mebendazole, which destroys larval cestodes in experimental animals and, in preliminary studies, appears to cause regression of hydatid cysts of $E$ granulosus and $E$ multilocularis in human patients.

Echinococcus multilocularis was first recognized in North America in the early $1950 \mathrm{~s}$, and since then 32 cases of human alveolar hydatid disease have been diagnosed in the northern tundra zone of Alaska. Since 1964 the cestode has been identified in animal hosts from an increasingly large area of central North America, including North Dakota, ${ }^{810}$ South Dakota, Minnesota, " Iowa, Montana, ${ }^{9}, 12$ Wyoming, ${ }^{13}$ Manitoba, ${ }^{14 \cdot 16}$ Saskatchewan, ${ }^{17-14}$ and Alberta. ${ }^{20}$ The important sylvatic hosts in these regions are red foxes, coyotes, deer mice, and field voles. The importation of the cestode into the central North American focus may have occurred by transport of infected dogs from Alaska ${ }^{21}$ or by southward migration of infected arctic foxes. The diagnosis of a human case of hydatid disease in Manitoba in $1928,{ }^{22}$ which, in retrospect, was apparently a locally acquired case of $E$ multilocularis, suggests that the cestode has been present there at least since the $1920 \mathrm{~s}$.
In Minnesota extensive parasitological surveys of foxes and rodents documented the absence of $E$ multilocularis through the $1940 \mathrm{~s}^{23-25}$ The cestode was first recognized in Minnesota as a result of studies carried out between 1965 and 1968 when infection was found in $5 \%$ of 277 foxes captured in various localities in the state." Since then the cestode has greatly increased its range and preva. lence rate. A conversation with F. J. Vande Vusse, PhD (Nov 9, 1978) disclosed that a survey of foxes carried out in the winter of 1977 to 1978 has shown infection in $49 \%$ of more than 250 foxes, thereby extending the known range of $E$ multilocularis from four to 20 counties in southwestern Minnesota.

Recent infections in pets or wild animals would not be the source of infection for this patient because more than ten years may elapse before clinical signs of disease in humans become apparent, but infections in carnivores are self-limiting after several months. ${ }^{26}$ Therefore, we can only guess at the particular source of infection in this case. Neither the patient nor her family engaged in hunting or other activities likely to expose her to foxes. It is more likely that the infection was acquired from a cat or dog that had eaten an infected vole or deer mouse. Although these pets did not enter the patient's house, their feces containing cestode eggs may have been carried into the house on contaminated clothing or footwear, or the patient might have been exposed while working outside. According to written communications from Delane C. Kritsky, $\mathrm{PhD}$, and Paul Leiby, PhD (May 16, 1978), infection in cats is a distinct possibility because recent surveys of farm cats in North Dakota have shown infection rates varying from $1 \%$ to $5 \%$ during the years 1971 to 1976.

The introduction and spread of $E$ multilocularis into Minnesota and adjacent states has serious implications. When restricted to sylvatic hosts, human exposure would be relatively uncommon except for hunters and other persons who might handle foxes or their skins. However, the enzootic occurrence of the cestode in local rodents represents a constant potential source of infection for cats 
and dogs in rural areas, and effective prevention could only be achieved by maintaining absolute control of movement of such pets at all times-a measure that is impractical.

Suitable sylvan animal hosts are present throughout most of the United States, and there are few barriers to prevent further extension of the cestode southward and east-

1. Rausch RL: Taeniidae, in Hubbert WT, McCulloch WF, Schnurrenberger PR (eds): Diseases Transmitted from Animals to Man, ed 6. Springfield, Ill, Charles C Thomas Publishers, 1975, pp 678-707.

2. Rausch RL, Wilson JF: Rearing of the adult Echinococcus multilocularis Leuckart, 1863 , from sterile larvae from man. Am J Trop Med Hyg 22:357-360, 1973.

3. Weinberg T: Echinococcus alveolaris infection of the human liver. J Mt Sinai Hosp 13:331$335,1947$.

4. LaFond DJ, Thatcher DS, Handeyside RG: Alveolar hydatid disease. JAMA 186:35-37, 1963.

5. Schantz PM, von Reyn CF, Welty T, et al: Echinococcosis in Arizona and New Mexico: Survey of hospital records, 1969-1974. Am J Trop Med Hyg 25:312-317, 1976.

6. Bekhti A, Schaaps JP, Capron M, et al: Treatment of hepatic hydatid disease with mebendazole: Preliminary results in four cases. Br Med J 2:1047-1051, 1977.

7. Wilson JF, Davidson M, Rausch RL: A clinical trial of mebondazole in the treatment of alveolar hydatid disease. Am Rev Respir Dis 118:747-757, 1978.

8. Leiby PD, Olsen OW: The cestode Echinococcus multilocularis in foxes in North Dakota. Science 145:1066, 1964.

9. Leiby PD, Carney WP, Woods CE: Studies on sylvatic echinococcosis: III. Host occurrence and geographic distribution of Echinococcus multilocularis in the north central United States. I Parasitol 56:1141-1150, 1970

10. Rausch RL, Richards SH: Observations on parasite host relationships of Echinococcus ward. If the parasite becomes established in cycles involving cats and house mice, it would permit entry into urban areas and even greater potential exposure of humans. ${ }^{27}$ More optimistically the apparent potential for widespread human infection may be limited by the low susceptibility of the human as host, as evidenced by the relatively low incidence of disease

\section{References}

multilocularis Leuckart, 1863 , in North Dakota. Can J Zool 49:1317-1330, 1971

11. Carney WP, Leiby PD: Echinococcus multilocularis in Peromyscus maniculatus and Vulpes vulpes from Minnesota. J Parasitol 54:714, 1968 .

12. Seesee FM, Worley DE: The occurrence of Echinococcus multilocularis Leuckart, 1863 (Cestoda:Taeniidae) in the red fox, Vulpes vulpes L., in southwestern Montana, abstract 49. 51st Annual Meeting of American Society of Parasitology, San Antonio, Aug 23-27, 1976.

13. Kritsky DC, Leiby PD, Miller GE: The natural occurrence of Echinococcus multilocularis in the bushy-tailed woodrat, Neotoma cinera rupicola, in Wyoming. Am $J$ Trop Med Hyg 26:1046-1047, 1977.

14. Leiby PD, Lubinsky G, Galaugher W: Studies on sylvatic echinococcosis: II. The occurrence of Echinococcus multilocularis Leuckart, 1863 in Manitoba. Can J Zool 47:135-138, 1969.

15. Lee CF: Larval Echinococcus multilocularis Leuckart, 1863 in the southern interlake area in Manitoba. Can J Zool 47:733-734, 1969.

16. Baron RW: The occurrence of Echinococcus multilocularis Leuckart, 1863 and of other helminths in the red fox, Vulpes vulpes, in southern Manitoba. Can J Zool 48:1132, 1970.

17. Hnatiuk JM: First occurrence of Echinococcus multilocularis Leuckart, 1863 in Microtus pennsylvanicus in Saskatchewan. Can $J$ Zool 44:493, 1966

18. Hnatiuk JM: Occurrence of Echinococcus multilocularis Leuckart, 1863 in Vulpes fulva in Saskatchewan. Can J Zool 47:264, 1969.

19. Wobeser G: The occurrence of Echinococ- in some heavily exposed Alaskan Eskimo populations.

Ortho Pharmaceutical Co, Raritan, NJ, provided mebendazole.

\section{Nonproprietary Name and Trademark of Drug}

Mebendazole-Vermox.

cus multilocularis (Leuckart, 1863) in cats near Saskatoon, Saskatchewan. Can Vet $J$ 12:65-68, 1971 .

20. Holmes JC, Mahrt JL, Samuel WM: The occurrence of Echinococcus multilocularis Leuckart, 1863 in Alberta. Can J Zool 49:575-576, 1961.

21. Rausch RL: On the ecology and distribution of Echinococcus spp. (Cestoda:Taeniidae), and characteristics of their development in the intermediate host. Ann Parasitol Hum Comp 42:19-63, 1967.

22. James E, Boyd W: Echinococcus alveolaris. Can Med Assoc J 36:354-356, 1937.

23. Erickson AB: Parasites of some Minnesota Cricetidae and Zapodidae, and a host catalogue of helminth parasites of native American mice. Am Midlands Naturalist 20:575-589, 1938.

24. Erickson AB: Helminths of Minnesota Canidae in relation to food habits, and a host list and key to the species reported from North America. Am Midlands Naturalist 32:358-372, 1944

25. Riley WA: Reservoirs of Echinococcus in Minnesota. Minn Med 16:744-745, 1933

26. Rausch R, Schiller EL: Studies on the helminth fauna of Alaska: XXV. The ecology and public health significance of Echinococcus sibiricensis Rausch and Schiller, 1954, on St. Lawrence Island. Parasitology 46:395-419, 1956.

27. Leiby PD, Kritsky DC: Echinococcus multilocularis: A possible domestic life cycle in central North America and its public health implications. J Parasitol 58:1213-1215, 1972. 